\title{
Physical and sanitary quality of soybean seeds produced in the state of Santa Catarina
}

\author{
Qualidade física e sanitária de sementes de soja produzidas no \\ estado de Santa Catarina
}

\author{
Volmir Frandoloso ${ }^{1}$; Geri Eduardo Meneghello²; César Iván Suárez Castellanos ${ }^{3 *}$; \\ Maria Ângela André Tillmann ${ }^{4}$; Cristiane Deuner ${ }^{3}$
}

\begin{abstract}
Soybean production accounts for approximately $43 \%$ of Brazil's grain produce, worth over 81 million tons for the 2012- 2013 cropping season. The use of quality seeds is essential for a high-yield agriculture, since low quality seeds compromise plant standing and increase production costs due to reseeding. This will in turn reduce yields through delays on the establishment dates. Seed quality is affected by relative humidity levels, mechanical damage during harvest and processing, thermal damage during the drying process and the environmental conditions during storage that could foster insect and fungi damage. The climate in the state of Santa Catarina favors soybean seed production, and seed companies in general work with high levels of technology. This work is aimed at characterizing the physical and sanitary quality of soybean seeds produced by different companies at different locations throughout the state of Santa Catarina (municipalities of Xanxerê, Abelardo Luz, Campos Novos and Canoinhas). The physical purity, moisture level, sanitary quality and mechanical damage of soybean seeds were studied at three stages, i.e. reception at the seed processing unit, at the end of the processing process and before being marketed. Results pointed out at mechanical injury and cultivar mixture as the main issues concerning seed lot quality, and that soybean seeds produced in Santa Catarina show pathogen contamination, which emphasizes the need for seed treatment.
\end{abstract}

Key words: Glycine $\max (\mathrm{L}$.) Merrill, harvest, seed processing, seed trade

\section{Resumo}

A cultura da soja representa aproximadamente $43 \%$ da produção de grãos no Brasil, produzindo-se acima de 81 milhões de toneladas na safra 2012-2013. A utilização de sementes de alta qualidade é crucial para uma agricultura produtiva. Sabe-se que sementes com baixa qualidade comprometem a obtenção de um adequado estande de plantas, influindo diretamente na produtividade da lavoura, aumentando os custos de produção pela ressemeadura, ocasionando frequentemente a perda da época adequada e trazendo problemas que refletem diretamente na produtividade. A qualidade de sementes pode ser afetada pelo grau de umidade, danos mecânicos na colheita e no beneficiamento, danos térmicos na secagem, condições ambientais de armazenamento e incidência de insetos e fungos. $\mathrm{O}$ Estado de Santa Catarina possui condições climáticas favoráveis para a produção de sementes de soja e

${ }^{1} \mathrm{Eng}^{\mathrm{o}} \mathrm{Ag}^{\mathrm{o}}$. Dr. Gerente Regional, Companhia Integral de Desenvolvimento Agrícola de Santa Catarina, CIDASC, Xanxerê, SC, Brasil. E-mail: volfrandoloso@yahoo.com.br

2 Eng $^{\circ}$ Agr $^{\circ}$, Pesquisador Dr., PPG em Ciência e Tecnologia de Sementes, Universidade Federal de Pelotas, UFPel, Bolsista de produtividade em pesquisa pelo CNPq, Pelotas, RS, Brasil. E-mail: gmeneghello@gmail.com

3 Discentes do curso de Doutorado em Ciência e Tecnologia de Sementes, UFPel, Pelotas, RS, Brasil. E-mail: cesarivansuarez@ gmail.com; cdeuner@yahoo.com.br

${ }^{4}$ Prof $^{\mathrm{a}} \mathrm{Dr}^{\mathrm{a}}$, Pós-Graduação em Ciência e Tecnologia de Sementes, UFPel, Pelotas, RS, Brasil. E-mail: matilman@ufpel.edu.br

* Author for correspondence 
empresas que dispõem de tecnologia moderna para a produção de sementes. Portanto, objetivou-se no presente experimento, caracterizar a qualidade física e sanitária das sementes de soja produzidas por empresas, em diferentes regiões do estado de Santa Catarina (Xanxerê, Abelardo Luz, Campos Novos e Canoinhas). Avaliou-se a pureza física, o dano mecânico, o grau de umidade e a qualidade sanitária de sementes em três épocas (recepção na UBS, após o beneficiamento e antes da comercialização). Os resultados obtidos permitiram concluir que a incidência de danos mecânicos e a mistura varietal são os principais problemas nos lotes de sementes de soja e que as sementes de soja produzidas no Estado de Santa Catarina apresentam contaminação por patógenos, recomendando-se o tratamento de sementes.

Palavras-chave: Beneficiamento, colheita, comercialização, Glycine max (L.) Merrill

\section{Introduction}

Soybean accounts for approximately $43 \%$ of Brazil's grain production, which was estimated at over 81 million tons for the 2012-2013 cropping season (CONAB, 2013). This production is dependent on high quality seed, since seed lots with low vigor will compromise the appropriate standing to achieve the yield potential (BINO et al., 1998), which will increase costs by means of re-sowing. Since inadequate stands take some time to reach crop establishment, whenever this practice is necessary it will imply the loss of time which will reflect directly upon productivity (KRZYZANOWSKI; FRANÇA NETO, 2003).

Low seed quality can be the result of adversities faced by the plant during seed development, or by other factors after seed maturation and before harvest. Also, excessive moisture, mechanical damage during harvest and processing, heat stress during drying, storage environment and pest and fungi incidence are factors that impact upon seed quality (POPINIGIS, 1985). Many of these injuries can compromise seed quality acting upon the physical attributes (physical and mechanical composition and moisture content of a seed lot) and seed health (harmful effects caused by the occurrence of microorganisms and insects).

One of the key issues that causing reductions on seed quality is the high rate of mechanical damage, which usually determines that the seed lot should be discarded (VICENZI, 2005). Mechanical damage can be caused by any equipment used from harvesting through to packaging (FESSEL;
BARRETO, 2000), and this could be not rapidly identified as it can cause invisible fractures that will manifest upon being put to germinate, originating abnormal seedlings (PESKE; BAUDET, 2012).

Seed moisture content is another limiting factor to seed quality, because high humidity accelerates the deterioration process, as it enhances metabolic activity. This implies consumption of reserve substances and loss of energy and water, favoring the growth of insects and microorganisms. Low seed moisture contents can also compromise seed quality by increasing the risk of damage caused by mechanical harvesting and transportation (PESKE; VILLELA, 2012). Another important factor to seed quality is the sanitary condition. Pathogens affect seed quality, affecting germination and vigor, with a negative impact on seed marketing as it reduces the availability of seed lots with good quality (LUCCA FILHO; FARIAS, 2012).

The climate in the state of Santa Catarina is favorable for the production of quality soybean seeds, with rainfall well distributed during the cropping season, warm temperatures at harvest and little change in the air's relative humidity during the storage period. Moreover, Santa Catarina harbors several companies and cooperatives that use the latest technology for seed production. These characteristics have led this state to be acknowledged as a producer of quality soybean seed.

Quality control of soybean seed production appears to be of fundamental importance, when considered within the context of supply chains. Some studies have shown that, despite the available 
technology, the quality of soybean seeds produced in some areas of the state of Santa Catarina has been severely compromised due to high damage caused by moisture, stink bug lesions, mechanical damage and seed coat cracks (MESQUITA et al., 1999; COSTA et al., 2001.).

In regard to all the factors intervening upon seed quality, this work aimed at the evaluation of the physical and sanitary quality of soybean seeds produced by companies from different locations of the state of Santa Catarina.

\section{Materials and Methods}

This work considered the major soybean seed production regions within the state of Santa Catarina, in the south of Brazil. Three cooperatives (Companies A, B and C) belong to the municipality of Xanxerê, two to the municipality of Abelardo Luz (D and E), another two (F and G) from Campos Novos and one $(\mathrm{H})$ from Canoinhas. Soybean seed samples (2 $\mathrm{kg}$ each) from three cultivars were collected at each of the eight locations on three dates, $i$ ) upon reception at the seed processing unit (SPU); ii) at the end of processing, and iii) before marketing (Table 1). Seed sampling was performed as established by the Brazilian Rules for Seed Testing (RAS) (BRASIL, 2009) and samples were packed into paper bags and sent over to the seed testing laboratory, where they remained stored under a cool, dry environment $\left(15^{\circ} \mathrm{C} / 40 \% \mathrm{RH}\right)$ until being analyzed for:
Physical quality: assessed through the physical purity of each sample, presence and number of seeds from other cultivars and from other species, according to RAS (BRASIL, 2009). A 500g sample was used to determine the physical purity and the quantification of seeds from other cultivars. Testing for noxious wild seeds was performed upon a 1,000 g sample, quantifying and identifying tolerated and forbidden noxious wild seeds.

Moisture content: performed by the Motomco 919'TM Moisture Meter.

Mechanical damage: Injury analysis for integument rupture was performed by treating two replicates of 100 seeds each to a 5\% sodium hypochlorite solution for 10 minutes. After removing the excess solution, the number of seeds with ruptured seed coats was determined, and the results expressed on a percentage basis.

Sanitary status: Detection of fungi on seeds was performed through the filter paper method, using 100 seeds divided into four replicates of 25 seeds each and placed in plastic boxes of the gerbox type, with four sheets of sterile filter paper dampened with distilled water. Incubation was carried out at $22^{\circ} \mathrm{C}$ with a photoperiod of $12 / 12$ hours for seven days. After this period, the fungi present in the seeds were identified with the aid of magnifying glass with lighting and a stereoscopic microscope (HENNING, 1994; GOULART, 1997). The results were expressed as percentages.

Table 1. List of soybean cultivars, locations and seed companies that participated in this study.

\begin{tabular}{ccc}
\hline LOCALITY & COMPANY & CULTIVAR / LOTS \\
\hline \multirow{2}{*}{ XANXERE } & A & NA 5909, CD 236 RR, NA 4990 RG \\
& B & CD 221, Don Mario 7.0i, CD 202 \\
& C & NS 4823, CD 202, NK 412113 \\
\hline \multirow{2}{*}{ ABELARDO LUZ } & D & Don Mario 5.8i, NA 4990 RG, BMX Potência RR. \\
& E & A.6411 RG, BMX Titan RR, NA 4990 RG \\
\hline \multirow{2}{*}{ CAMPOS NOVOS } & F & BRS 294, Don Mario 7.0i, BRS 295 \\
& G & Don Mario 5.8i, BMX Energia RR, NS 4823 RG. \\
\hline CANOINHAS & H & NK 7059 RR, SYN 3358 RR, SYN 1049 RR \\
\hline
\end{tabular}


Statistical analysis was carried out individually for each site and company, in a completely randomized $3 \times 3$ factorial scheme, where the first factor was the cultivars (three cultivars company, varying among the companies studied) and the second factor the time of evaluation (reception at the SPU, end of the processing and marketing). Data were subjected to analysis of variance using the statistical program WinStat 1.0 (MACHADO; CONCEIÇÃO, 2003) and means compared by the Duncan test at $\mathrm{P}<0.05$. Data expressed as percentages were transformed using the $\arcsin \sqrt{ } \mathrm{x} / 100$ factor.

\section{Results and Discussion}

Table 2 shows the results of the analysis of physical purity and seeds of other cultivars. It can be observed that during the time interval between the end of processing and prior to marketing, physical purity of all cultivars is consistent with the standards for seed production, i.e. $99 \%$ purity for certified seed.

Table 2. Results from the seed purity test (SP) and seeds from other cultivars (SOC) from soybean seed lots, pertaining to eight seed companies from different locations in the state of Santa Catarina, Brazil.

\begin{tabular}{|c|c|c|c|c|c|c|c|c|}
\hline \multirow{3}{*}{ Locality } & \multirow{3}{*}{ Company } & \multirow{3}{*}{ Cultivar } & \multicolumn{6}{|c|}{ TIME } \\
\hline & & & \multicolumn{2}{|c|}{ Reception at Spu } & \multicolumn{2}{|c|}{ End of Processing } & \multicolumn{2}{|c|}{ Before Marketing } \\
\hline & & & SP (\%) & $\operatorname{SOC}\left(n^{\circ}\right)$ & SP (\%) & $\operatorname{SOC}\left(n^{\circ}\right)$ & SP (\%) & $\operatorname{SOC}\left(n^{\circ}\right)$ \\
\hline \multirow{9}{*}{ XANXERÊ } & \multirow{3}{*}{ A } & NA 5909 & 97,4 & 3 & 99,7 & 2 & 99,8 & 1 \\
\hline & & CD 236 & 96,8 & 1 & 99,8 & 1 & 99,9 & Zero \\
\hline & & NA4990 & 96,9 & Zero & 99,9 & Zero & 99,9 & Zero \\
\hline & \multirow{3}{*}{ B } & CD 221 & 97,7 & 2 & 99,7 & Zero & 99,7 & Zero \\
\hline & & DON MARIO 7.0 I & 97,8 & 4 & 99,7 & 4 & 99,7 & 3 \\
\hline & & CD 202 & 98,2 & Zero & 99,7 & Zero & 99,8 & 2 \\
\hline & \multirow{3}{*}{$\mathrm{C}$} & NS 4823 & 96,7 & Zero & 99,8 & Zero & 99,9 & Zero \\
\hline & & CD 202 & 97,4 & 1 & 99,8 & Zero & 99,9 & Zero \\
\hline & & NK 412113 & 97,3 & Zero & 99,8 & Zero & 99,8 & Zero \\
\hline \multirow{6}{*}{$\begin{array}{l}\text { ABELARDO } \\
\text { LUZ }\end{array}$} & \multirow{3}{*}{$\mathrm{D}$} & DON MARIO 5.8I & 97,5 & 2 & 99,4 & 3 & 99,6 & 2 \\
\hline & & NA 4990 & 97,6 & Zero & 99,7 & Zero & 99,8 & Zero \\
\hline & & BMX POTÊNCIA & 97,4 & Zero & 99,5 & Zero & 99,6 & Zero \\
\hline & \multirow{3}{*}{$\mathrm{E}$} & A 6411 & 96,8 & 5 & 99,8 & 6 & 99,9 & 6 \\
\hline & & BMX TITAN & 97,2 & Zero & 99,7 & Zero & 100 & Zero \\
\hline & & NA 4990 & 97,2 & Zero & 99,7 & Zero & 99,8 & Zero \\
\hline \multirow{6}{*}{$\begin{array}{l}\text { CAMPOS } \\
\text { NOVOS }\end{array}$} & \multirow{3}{*}{$\mathrm{F}$} & BRS 294 & 96,8 & Zero & 99,6 & Zero & 99,8 & Zero \\
\hline & & DON MARIO $7.0 \mathrm{I}$ & 97,2 & 5 & 99,4 & 8 & 99,7 & 6 \\
\hline & & BRS 295 & 97,8 & 1 & 99,4 & 2 & 99,7 & 1 \\
\hline & \multirow{3}{*}{ G } & DON MARIO 5.8 I & 96,9 & 4 & 99,6 & 1 & 99,7 & 1 \\
\hline & & BMX ENERGIA & 97,4 & 2 & 99,6 & 1 & 99,8 & 1 \\
\hline & & NS 4823 & 97,6 & Zero & 99,6 & Zero & 99,7 & Zero \\
\hline \multirow{3}{*}{ CANOINHAS } & \multirow{3}{*}{$\mathrm{H}$} & NK7059 & 97,7 & Zero & 99,7 & Zero & 99,8 & Zero \\
\hline & & SYN 3358 & 98,2 & Zero & 99,9 & Zero & 99,9 & Zero \\
\hline & & SYN 1049 & 97,7 & 3 & 99,7 & 1 & 99,8 & Zero \\
\hline
\end{tabular}

The results of the examination of noxious, tolerated and banned seeds, were nil in all lots of the cultivars analyzed, complying with the required standard for certified seed. The seeds of other cultivars (Table 2) showed that most of the cultivars had some level of contamination upon reception 
at the SPU. After processing some cultivars maintained their original levels of contamination, and other, increased them or showed a reduction of initial levels of contamination.

Varietal mixture occurred to greater or lesser degrees in all companies studied, whether at harvest or after processing. These findings may be related to flaws in crop management or lack of care in verifying cleanliness of the equipment involved in harvest, transportation, drying and processing of the seed.

At the time before being marketed (Table 2), the majority of the cultivars complied with the standards for purity and presence of seeds from other cultivars, required for certified seed of the category "C2". However, two cultivars showed higher rates for seed contamination than the standard accepted by MAPA (Ministry of Agriculture and Livestock). The Normative Instruction 25, of December 16, 2005 , establishes that only up to five (5) seeds from other cultivars are acceptable for seeds of category "C2". If these cultivars were demoted from that category to "S2", they would fall within the required standards. According to Vicenzi (2005), to prevent varietal mixture care should be taken in the cleanup of all the machinery and equipment involved, whether in harvesting or seed processing, especially when shifting from one cultivar to another. According to the same author, after a 14-year (1999-2004) survey conducted by a seed cooperative in Santa Catarina on 5,983 lots of soybean seeds, $16 \%$ of them showed levels of contamination by seeds of other cultivars above the standard accepted for certified seed (five contaminating seeds per lot for category $\mathrm{C} 2$ ), considering the current legislation at the time.

The moisture content for the seeds of all cultivars upon reception at the respective SPUs ranged from 11.2 to $14.8 \%$. In municipalities of Xanxerê and Abelardo Luz had not significant difference in seed moisture between the reception at SPU and after processing, but statistical difference was found in the moisture prior to marketing, which was lower and ranged of 9.1 to $11.8 \%$. Among the municipalities of Campos Novos and Canoinhas, it was observed that seed moisture content had significantly higher at reception at the SPU compared with moisture after processing and before marketing (Table 3). Peske and Villela (2012) reported that soybean seeds with moisture content between $11 \%$ and $12 \%$ can be stored for a period of six to eight months, without experiencing serious damage to their quality. However, seeds with low moisture content suffer greater mechanical damage leading to integument cracking and rupturing during harvest, which could have a direct impact on the maintenance of seed quality during processing and storage. To avoid this type of damage, the desirable range for moisture content at harvest should be from $14.0 \%$ to $18.0 \%$. Seeds harvested within this range are less prone to mechanical damage as well as to losses during harvest. With moisture contents at harvest in the range of $11.4 \%$ to $19 \%$, the level of injury is acceptable and losses will remain below 3\%. The combination of low seed moisture and high cylinder rotation from the combine will result in increased mechanical damage (HAMER; PESKE, 1997).

Regarding the mechanical damage to seeds shown on Table 4, the highest levels for injured seeds were recorded upon reception at the SPU, with some seed lots showing slight increases after undergoing processing. One of the factors that may be associated with a high degree of mechanical damage, especially during reception at the SPU and in some cases during processing, is low moisture content in the seeds directly from the field. Many cultivars were harvested and processed with moisture contents below $12 \%$, which contributes to the occurrence of seed coat cracks, and broken seeds, common traits for seed lots with low moisture levels. Another factor that contributes to mechanical damage at harvest is the use of combines in which the crop is fed tangentially into a cross-mounted cylinder-concave assembly, a popular type for seed producers and companies that are part of this study. 
Table 3. Results for the moisture content of soybean seeds along three different stages of the production chain, pertaining to eight seed companies from different locations in the state of Santa Catarina. Brazil.

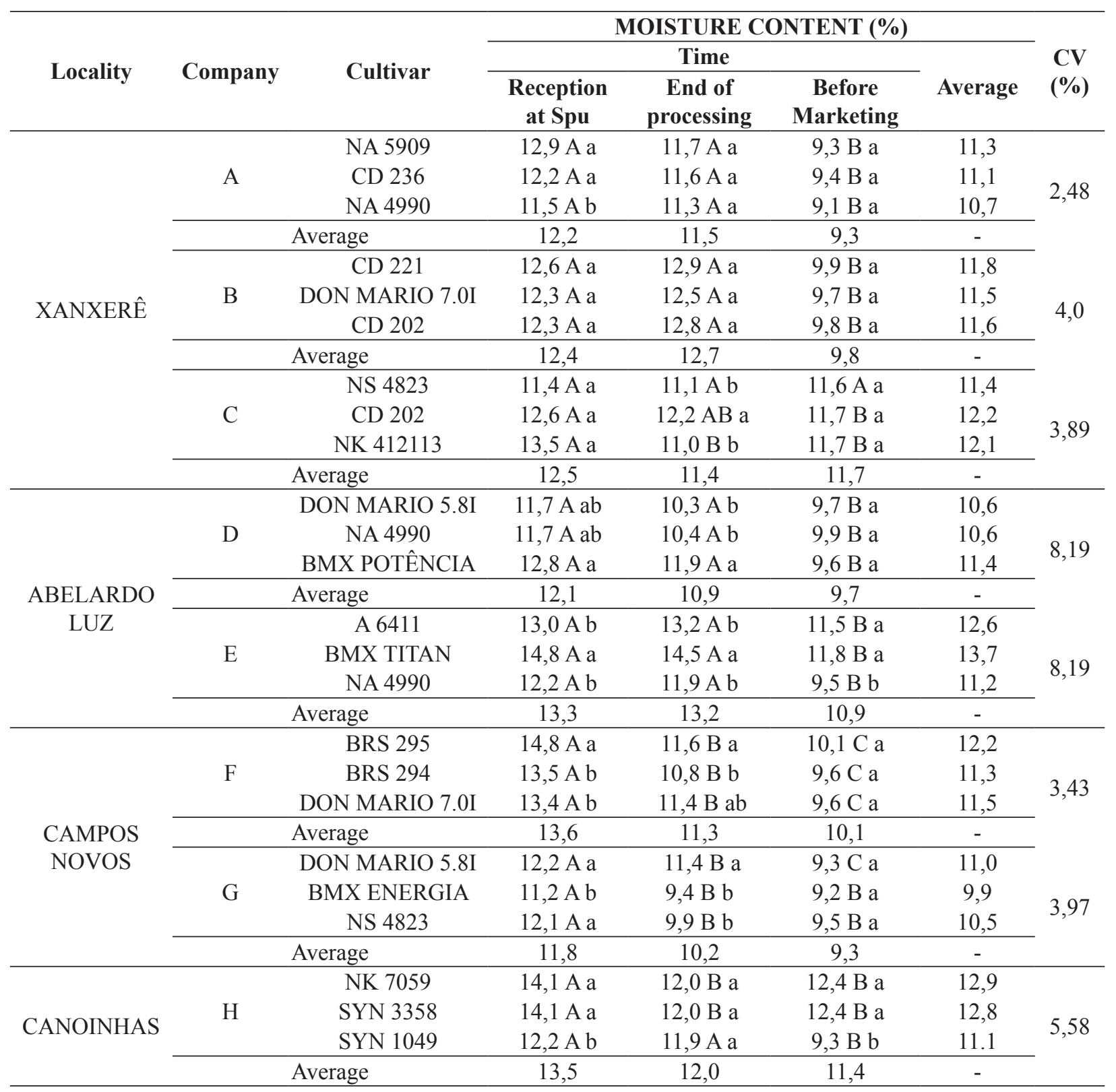

Data followed by different letters (uppercase in the line and lowercase in the column) are significantly different at the $\mathrm{p}<0.05$ level according to Duncan test.

França Neto et al. (1998) indicate that due to the aggressiveness of this operation, mechanical harvesting of soybean is considered expensive and many times providing a medium-quality product, reflecting lack of combine maintenance as well as for the necessary adjustments for the threshing, separation and cleaning systems. According to these authors, soybeans are very sensitive to mechanical impact, since the vital parts of the embryo, as radicle, hypocotyl and plumule are located under a thin seed coat that barely offers any protection.

The mechanical damage has a cumulative effect, i.e., the damage caused by a previous impact will sum up to that of a new impact. With each new impact, each seed becomes increasingly sensitive 
to damage (CARVALHO; NAKAGAWA, 2000). processed and handled properly, otherwise all care Fessel and Barreto (2000) have pointed out that and investments provided during field development this process makes clear the seed needs to be will be lost.

Table 4. Results for the mechanical damage of soybean seeds along three different stages of the production chain, pertaining to eight seed companies from different locations in the state of Santa Catarina. Brazil.

\begin{tabular}{|c|c|c|c|c|c|c|c|}
\hline \multirow{3}{*}{ Locality } & \multirow{3}{*}{ Company } & \multirow{3}{*}{ Cultivar } & \multicolumn{4}{|c|}{ MECANICAL DAMAGE (\%) } & \multirow{3}{*}{$\begin{array}{l}\text { CV } \\
(\%)\end{array}$} \\
\hline & & & \multicolumn{3}{|c|}{ Time } & \multirow[b]{2}{*}{ Average } & \\
\hline & & & $\begin{array}{c}\text { Reception at } \\
\text { Spu }\end{array}$ & $\begin{array}{c}\text { End of } \\
\text { Processing }\end{array}$ & $\begin{array}{c}\text { Before } \\
\text { Marketing }\end{array}$ & & \\
\hline \multirow{12}{*}{ XANXERÊ } & \multirow{3}{*}{ A } & NA 5909 & $11 \mathrm{~A} \mathrm{a}$ & $10 \mathrm{~A} \mathrm{a}$ & $9 \mathrm{Aa}$ & 10 & \multirow{4}{*}{0,81} \\
\hline & & CD 236 & $10 \mathrm{~A} \mathrm{a}$ & $8 \mathrm{~A} \mathrm{a}$ & $8 \mathrm{~A} \mathrm{a}$ & 9 & \\
\hline & & NA 4990 & $5 \mathrm{Ab}$ & $5 \mathrm{Ab}$ & $6 \mathrm{Ab}$ & 5 & \\
\hline & \multicolumn{2}{|c|}{ Average } & 9 & 7 & 8 & - & \\
\hline & \multirow{3}{*}{ B } & CD 221 & $11 \mathrm{~B} \mathrm{a}$ & $12 \mathrm{~B} \mathrm{a}$ & $15 \mathrm{~A} \mathrm{a}$ & 13 & \multirow{4}{*}{3,70} \\
\hline & & $\begin{array}{c}\text { DON } \\
\text { MARIO 7.0I }\end{array}$ & $9 \mathrm{~B}$ ab & $12 \mathrm{~A} \mathrm{a}$ & $9 \mathrm{~B} \mathrm{~b}$ & 10 & \\
\hline & & CD 202 & $9 \mathrm{~B} \mathrm{~b}$ & $12 \mathrm{Ab}$ & $12 \mathrm{~A} \mathrm{a}$ & 11 & \\
\hline & \multirow{4}{*}{$\mathrm{C}$} & rage & 10 & 12 & 12 & - & \\
\hline & & NS 4823 & $13 \mathrm{~A} \mathrm{a}$ & $11 \mathrm{~A} \mathrm{a}$ & $10 \mathrm{~A} \mathrm{a}$ & 11 & \multirow{4}{*}{3,69} \\
\hline & & CD 202 & $12 \mathrm{~A} \mathrm{a}$ & $11 \mathrm{~A} \mathrm{a}$ & $10 \mathrm{~A} \mathrm{a}$ & 11 & \\
\hline & & NK 412113 & $13 \mathrm{~A} \mathrm{a}$ & $14 \mathrm{~A} \mathrm{a}$ & $10 \mathrm{~B} \mathrm{a}$ & 12 & \\
\hline & & rage & 13 & 12 & 10 & - & \\
\hline \multirow{8}{*}{$\begin{array}{l}\text { ABELARDO } \\
\text { LUZ }\end{array}$} & \multirow{3}{*}{$\mathrm{D}$} & $\begin{array}{c}\text { DON } \\
\text { MARIO 5.8I }\end{array}$ & $8 \mathrm{~B} \mathrm{c}$ & $13 \mathrm{~A} \mathrm{a}$ & $15 \mathrm{~A} \mathrm{a}$ & 12 & \multirow{4}{*}{4,82} \\
\hline & & NA 4990 & $10 \mathrm{Ab}$ & $10 \mathrm{Ab}$ & $12 \mathrm{Ab}$ & 10 & \\
\hline & & $\begin{array}{c}\text { BMX } \\
\text { POTÊNCIA }\end{array}$ & $16 \mathrm{~A} \mathrm{a}$ & $18 \mathrm{~A} \mathrm{a}$ & $18 \mathrm{~A} \mathrm{a}$ & 17 & \\
\hline & \multirow{4}{*}{$\mathrm{E}$} & rage & 12 & 13 & 15 & - & \\
\hline & & A 6411 & $13 \mathrm{~A} \mathrm{a}$ & $11 \mathrm{Aa}$ & $9 \mathrm{~A} \mathrm{a}$ & 11 & \multirow{4}{*}{4,82} \\
\hline & & BMX TITAN & $11 \mathrm{~A} \mathrm{a}$ & $11 \mathrm{~A} \mathrm{a}$ & $9 \mathrm{~A} \mathrm{a}$ & 10 & \\
\hline & & NA 4990 & $10 \mathrm{~A} \mathrm{a}$ & $10 \mathrm{~A} \mathrm{a}$ & $13 \mathrm{~A} \mathrm{a}$ & 11 & \\
\hline & & rage & 11 & 11 & 10 & - & \\
\hline \multirow{8}{*}{$\begin{array}{c}\text { CAMPOS } \\
\text { NOVOS }\end{array}$} & \multirow{3}{*}{$\mathrm{F}$} & BRS 295 & $15 \mathrm{~B} \mathrm{a}$ & $18 \mathrm{~A} \mathrm{a}$ & $15 \mathrm{~B} \mathrm{a}$ & 16 & \multirow{4}{*}{4,22} \\
\hline & & BRS 294 & $12 \mathrm{~B} \mathrm{a}$ & $17 \mathrm{~A} \mathrm{a}$ & $13 \mathrm{~B} \mathrm{a}$ & 14 & \\
\hline & & $\begin{array}{c}\text { DON } \\
\text { MARIO 7.0I }\end{array}$ & $15 \mathrm{~A} \mathrm{a}$ & $16 \mathrm{~A} \mathrm{a}$ & $15 \mathrm{~A} \mathrm{a}$ & 15 & \\
\hline & & rage & 14 & 17 & 14 & - & \\
\hline & \multirow{3}{*}{ G } & $\begin{array}{c}\text { DON } \\
\text { MARIO 5.8I }\end{array}$ & $13 \mathrm{~A} \mathrm{a}$ & $15 \mathrm{~A} \mathrm{a}$ & $13 \mathrm{~A} \mathrm{a}$ & 14 & \multirow{4}{*}{3,16} \\
\hline & & $\begin{array}{c}\text { BMX } \\
\text { ENERGIA }\end{array}$ & $5 \mathrm{~B} \mathrm{~b}$ & $7 \mathrm{AB} \mathrm{b}$ & $10 \mathrm{~A} \mathrm{a}$ & 8 & \\
\hline & & NS 4823 & $8 \mathrm{~B} \mathrm{~b}$ & $12 \mathrm{~A} \mathrm{a}$ & $13 \mathrm{~A} \mathrm{a}$ & 11 & \\
\hline & & rage & 9 & 11 & 12 & - & \\
\hline \multirow{4}{*}{ CANOINHAS } & & NK 7059 & $10 \mathrm{Ab}$ & $11 \mathrm{Aa}$ & $9 \mathrm{~A} \mathrm{a}$ & 10 & \multirow{4}{*}{3,24} \\
\hline & $\mathrm{H}$ & SYN 3358 & $12 \mathrm{~A} \mathrm{a}$ & $13 \mathrm{~A} \mathrm{a}$ & $10 \mathrm{~A} \mathrm{a}$ & 12 & \\
\hline & & SYN 1049 & $3 \mathrm{~B} \mathrm{c}$ & $8 \mathrm{Ab}$ & $8 \mathrm{Aa}$ & 6 & \\
\hline & & rage & 8 & 11 & 9 & & \\
\hline
\end{tabular}

Data followed by different letters (uppercase in the line and lowercase in the column) are significantly different at the $\mathrm{p}<0.05$ level according to Duncan test. 
It was observed also that for all locations levels of broken seed, seed coat cracking and mechanical damage were significant for seeds of most cultivars (Table 4), indicating that soybean is highly sensitive to mechanical impact. However, the variations of mechanical damage found in this study do not establish a clear pattern of how and where the greatest damage occurring seeds, since the mechanical damage depends on several factors that stand in the seed moisture, equipment used when handling seeds and calibration thereof and different characteristics between regions. França Neto and Henning (1984) emphasize that harvest is the time at which mechanical damage peaks, severely affecting the quality of the seed produced in some soybean producing regions.

Considering the role of harvest on mechanical damage, the problem can be alleviated if soybean seed producers from the state of Santa Catarina apply harvest technologies such as those described by Costa et al. (1994, 1996) and Mesquita et al. (1999). According to these authors, rigorous adjustments to the combine systems as well as daily monitoring of seed moisture, especially during the hottest periods of the day, are strategies to effectively reduce seed losses.

Regarding the results of seed health analysis of lots of cultivars evaluated in different companies, regions (Xanxerê, Abelardo Luz, Campos Novos and Canoinhas) and time of assessment (Reception at SPU, after processing and prior to marketing) found the following fungi: Cercospora spp., Fusarium spp., Aspergillus spp., Phomopsis sp., Penicillium spp. and Colletotrichum sp. (Tables 5 to 8). According to the Brazilian Rules for Seed Testing (RAS) (BRASIL, 2009), the aim of sanitary testing is to establish the level of seed health of a sample, thus reflecting that of the specific lot. Therefore, lots can be ranked to enable seed quality comparisons among them or to determine their commercial use. Comparing the results for sanitary levels of seed lots from the different soybean cultivars across cooperatives and sampling stages (Tables 5 to 8), it can be observed that there was a higher incidence of fungi of the genera Fusarium sp., Cercospora spp., Phomopsis sp., and Aspergillus spp. Fungi from the genus Fusarium sp. showed the highest incidence throughout all evaluation periods. This genus is related to the seed rot and may cause death even before radicle protrusion (FRANÇA NETO; HENNING, 1984). The occurrence of genus Cercospora spp. was uniform and with high incidence. This genus deserves special attention because infected seeds constitute the primary source of inoculum (PASCHAL; ELLIS, 1978; SINCLAIR, 1982; MENTEN, 1991), equal to that found other pathogens. Fungi from the genus Phomopsis sp. were also found at medium to high incidence. It is considered important because they affect seed quality by reducing germination levels, thus resulting in poor stands and the emergence of weak seedlings with systemic infection (PASCHAL; ELLIS, 1978; FRANÇA NETO; HENNING, 1984). If seed maturation and harvest coincide with rainy periods, infection by Phomopsis sp. will be favored, as already demonstrated by Tekrony et al. (1983), Balducchi and McGee (1987) and Sinclair (1991).

The relative importance of fungi genera during the storage period showed the incidence of Aspergillus sp. and Penicillium spp. as the most relevant. The relatively higher incidence of Aspergillus sp. was probably favored by rainfall at harvest time. Typically, storage fungi do not infect seeds before harvest, but on occasions they have been found in very low levels, around $1 \%$, in tests performed on freshly harvested seeds. They may be present in the seed not only as contaminants, but also as dormant mycelium within the seed coat tissue. One of the characteristics of these microorganisms is their efficiency of propagation, since although present in the field at very low levels they are able to multiply rapidly under favorable environmental conditions. 
Table 5. Seed sanitary quality (\% of pathogen occurrence) for soybean seed lots from the Xanxerê/SC location, pertaining to three seed companies and sampled along three stages of the production chain.

\begin{tabular}{|c|c|c|c|c|c|c|c|c|c|c|c|}
\hline \multirow{4}{*}{ TIME } & \multirow{4}{*}{ GENUS } & \multicolumn{9}{|c|}{ COMPANY } & \multirow{4}{*}{$\begin{array}{c}\text { INCIDENCE } \\
(\%)\end{array}$} \\
\hline & & \multicolumn{3}{|c|}{$\mathbf{A}$} & \multirow{2}{*}{\multicolumn{3}{|c|}{$\begin{array}{c}\text { B } \\
\text { CULTIVAR } \\
\end{array}$}} & \multirow{2}{*}{\multicolumn{3}{|c|}{$\mathrm{C}$}} & \\
\hline & & & & & & & & & & & \\
\hline & & $\begin{array}{c}\text { NA } \\
5909\end{array}$ & $\begin{array}{l}\text { CD } \\
236\end{array}$ & $\begin{array}{c}\text { NA } \\
4990\end{array}$ & $\begin{array}{l}\text { CD } \\
221\end{array}$ & $\begin{array}{c}\text { DON } \\
\text { MARIO } \\
7.0 I\end{array}$ & $\begin{array}{l}\text { CD } \\
202\end{array}$ & $\begin{array}{c}\text { NS } \\
4823\end{array}$ & $\begin{array}{l}\text { CD } \\
202\end{array}$ & $\begin{array}{c}\text { NK } \\
412113\end{array}$ & \\
\hline \multirow{6}{*}{$\begin{array}{l}\text { RECEPTION AT } \\
\text { SPU }\end{array}$} & Cercospora & 10,3 & 4,6 & 5,6 & 10,7 & 7,7 & 3,3 & 0,0 & 3,3 & 10,7 & 88,90 \\
\hline & Fusarium & 2,6 & 17,3 & 8,0 & 15,3 & 13,3 & 14,0 & 3,7 & 16,7 & 22,3 & 100 \\
\hline & Phomopsis & 3,0 & 2,0 & 4,0 & 1,7 & 3,7 & 4,3 & 3,0 & 3,0 & 6,7 & 100 \\
\hline & Aspergillus & 0,0 & 0,0 & 0,0 & 0,0 & 0,0 & 0,0 & 0,0 & 0,0 & 3,0 & 11,10 \\
\hline & Penicillium & 0,0 & 0,0 & 1,0 & 0,0 & 0,0 & 0,0 & 15,0 & 0,0 & 0,0 & 22,20 \\
\hline & Colletotrichum & 0,0 & 10,3 & 2,3 & 0,0 & 0,0 & 0,0 & 0,0 & 0,0 & 0,0 & 22,10 \\
\hline \multirow{6}{*}{$\begin{array}{c}\text { END OF } \\
\text { PROCESSING }\end{array}$} & Cercospora & 3,3 & 6,3 & 1,3 & 3,7 & 4,3 & 10,6 & 2,7 & 1,7 & 6,0 & 100 \\
\hline & Fusarium & 2,6 & 2,7 & 4,3 & 1,3 & 8,7 & 3,0 & 11,0 & 9,7 & 11,7 & 100 \\
\hline & Phomopsis & 0,7 & 0,7 & 0,0 & 0,7 & 0,7 & 0,7 & 4,7 & 1,3 & 6,0 & 88,90 \\
\hline & Aspergillus & 2,3 & 2,7 & 6,0 & 57,0 & 3,0 & 6,0 & 22,3 & 16,0 & 19,7 & 100 \\
\hline & Penicillium & 0,0 & 0,0 & 0,3 & 0,0 & 0,3 & 0,0 & 0,0 & 0,0 & 0,0 & 22,20 \\
\hline & Colletotrichum & 0,0 & 0,0 & 0,0 & 0,0 & 0,0 & 0,0 & 0,0 & 0,0 & 0,0 & 0,0 \\
\hline \multirow{6}{*}{$\begin{array}{c}\text { BEFORE } \\
\text { MARKETING }\end{array}$} & Cercospora & 1,6 & 1,3 & 0,3 & 1,7 & 5,7 & 1,6 & 0,7 & 1,7 & 7,0 & 100,0 \\
\hline & Fusarium & 0,0 & 3,0 & 0,7 & 3,0 & 1,7 & 7,0 & 1,7 & 12,7 & 4,0 & 88,90 \\
\hline & Phomopsis & 0,7 & 0,7 & 0,0 & 2,7 & 0,7 & 0,3 & 1,7 & 4,3 & 2,3 & 88,90 \\
\hline & Aspergillus & 11,3 & 9,3 & 27,7 & 34,0 & 4,0 & 2,3 & 26,0 & 34,0 & 6,0 & 100,0 \\
\hline & Penicillium & 0,0 & 0,0 & 0,3 & 0,0 & 0,0 & 8,7 & 0,0 & 0,0 & 0,0 & 22,20 \\
\hline & Colletotrichum & 0,0 & 0,0 & 0,0 & 0,0 & 0,0 & 0,0 & 0,0 & 0,0 & 0,0 & 0,0 \\
\hline
\end{tabular}

Table 6. Seed sanitary quality (\% of pathogen occurrence) for soybean seed lots from the Abelardo Luz/SC location, pertaining to two seed companies and sampled along three stages of the production chain.

\begin{tabular}{|c|c|c|c|c|c|c|c|c|}
\hline \multirow{4}{*}{ TIME } & \multirow{4}{*}{ GENUS } & \multicolumn{6}{|c|}{ COMPANY } & \multirow{4}{*}{$\begin{array}{c}\text { INCIDENCE } \\
(\%)\end{array}$} \\
\hline & & \multicolumn{3}{|c|}{ D } & \multicolumn{3}{|c|}{$\mathbf{E}$} & \\
\hline & & \multicolumn{6}{|c|}{ CULTIVAR } & \\
\hline & & A 6411 & $\begin{array}{l}\text { BMX } \\
\text { TITAN }\end{array}$ & NA 4990 & $\begin{array}{c}\text { DOM } \\
\text { MARIO } \\
5.8 I\end{array}$ & NA 4990 & $\begin{array}{c}\text { BMX } \\
\text { POTÊNCIA }\end{array}$ & \\
\hline \multirow{6}{*}{$\begin{array}{l}\text { RECEPTION } \\
\text { AT SPU }\end{array}$} & Cercospora & 0,0 & 4,3 & 5,3 & 20,7 & 10,7 & 0,0 & 66,70 \\
\hline & Fusarium & 7,3 & 13,3 & 14,3 & 16,0 & 15,7 & 8,7 & 100 \\
\hline & Phomopsis & 0,0 & 6,3 & 6,7 & 1,0 & 0,7 & 2,0 & 83,33 \\
\hline & Aspergillus & 4,7 & 6,0 & 1,3 & 0,0 & 0,0 & 17,7 & 66,70 \\
\hline & Penicillium & 2,0 & 0,0 & 0,0 & 0,0 & 0,0 & 0,0 & 16,70 \\
\hline & Colletotrichum & 0,0 & 0,0 & 0,0 & 0,0 & 0,0 & 0,0 & 0,00 \\
\hline \multirow{6}{*}{$\begin{array}{c}\text { END OF } \\
\text { PROCESSING }\end{array}$} & Cercospora & 7,3 & 3,3 & 0,7 & 5,7 & 3,7 & 5,7 & 100 \\
\hline & Fusarium & 3,7 & 12,7 & 6,0 & 8,0 & 23,3 & 9,6 & 100 \\
\hline & Phomopsis & 0,0 & 2,3 & 1,0 & 1,0 & 7,0 & 6,3 & 3,33 \\
\hline & Aspergillus & 0,7 & 17,7 & 5,3 & 8,7 & 10,0 & 24,7 & 100 \\
\hline & Penicillium & 0,0 & 0,0 & 0,7 & 0,0 & 0,0 & 1,0 & 33,33 \\
\hline & Colletotrichum & 0,0 & 0,0 & 0,0 & 0,0 & 0,0 & 0,3 & 16,70 \\
\hline
\end{tabular}


continuação

\begin{tabular}{cccccccccc}
\hline & Cercospora & 4,0 & 6,0 & 11,7 & 2,0 & 2,7 & 4,7 & 100 \\
& Fusarium & 5,0 & 18,3 & 12,7 & 3,0 & 10,0 & 5,0 & 100 & 50,0 \\
BEFORE & Phomopsis & 0,0 & 9,0 & 6,0 & 0,0 & 0,0 & 3,3 & 100 \\
MARKETING & Aspergillus & 7,7 & 9,7 & 15,0 & 10,7 & 10,3 & 15,0 & 33,33 \\
& Penicillium & 0,0 & 0,0 & 0,0 & 0,0 & 0,3 & 0,7 & 0,0 & 16,70 \\
\hline
\end{tabular}

Table 7. Seed sanitary quality (\% of pathogen occurrence) for soybean seed lots from the Campos Novos/SC location, pertaining to two seed companies and sampled along three stages of the production chain.

\begin{tabular}{|c|c|c|c|c|c|c|c|c|}
\hline \multirow{4}{*}{ TIME } & \multirow{4}{*}{ GENUS } & \multicolumn{6}{|c|}{ COMPANY } & \multirow{4}{*}{$\begin{array}{c}\text { INCIDENCE } \\
(\%)\end{array}$} \\
\hline & & \multicolumn{3}{|c|}{$\mathbf{F}$} & \multicolumn{3}{|c|}{ G } & \\
\hline & & \multicolumn{6}{|c|}{ CULTIVAS } & \\
\hline & & BRS 294 & $\begin{array}{c}\text { DON } \\
\text { MARIO } \\
7.0 I\end{array}$ & BRS 295 & $\begin{array}{c}\text { DON } \\
\text { MARIO } \\
5.8 I\end{array}$ & $\begin{array}{c}\text { BMX } \\
\text { ENERGIA }\end{array}$ & NS 4823 & \\
\hline \multirow{6}{*}{$\begin{array}{l}\text { RECEPTION AT } \\
\text { SPU }\end{array}$} & Cercospora & 1,3 & 5,3 & 23,3 & 15,7 & 9,7 & 4,0 & 100,0 \\
\hline & Fusarium & 16,7 & 14,7 & 25,7 & 16,7 & 15,7 & 5,0 & 100,0 \\
\hline & Phomosis & 0,0 & 6,0 & 33,0 & 0,0 & 0,0 & 0,0 & 33,33 \\
\hline & Aspergillus & 11,3 & 0,0 & 0,0 & 0,0 & 0,0 & 0,0 & 16,70 \\
\hline & Penicillium & 0,0 & 0,0 & 0,0 & 5,7 & 7,7 & 0,0 & 33,33 \\
\hline & Colletotrichum & 0,0 & 0,0 & 0,0 & 0,0 & 1,0 & 3,7 & 33,33 \\
\hline \multirow{6}{*}{$\begin{array}{c}\text { END OF } \\
\text { PROCESSING }\end{array}$} & Cercospora & 3,3 & 3,7 & 15,0 & 21,0 & 8,3 & 10,7 & 100 \\
\hline & Fusarium & 5,7 & 10,7 & 30,0 & 10,0 & 6,0 & 8,7 & 100 \\
\hline & Phomosis & 0,7 & 10,0 & 20,3 & 2,3 & 3,0 & 1,7 & 100 \\
\hline & Aspergillus & 2,0 & 1,0 & 1,0 & 0,0 & 0,3 & 1,0 & 83,33 \\
\hline & Penicillium & 0,0 & 0,0 & 0,0 & 0,0 & 0,0 & 0,0 & 0,00 \\
\hline & Colletotrichum & 0,0 & 0,0 & 0,0 & 0,0 & 0,0 & 0,0 & 0,00 \\
\hline \multirow{6}{*}{$\begin{array}{c}\text { BEFORE } \\
\text { MARKETING }\end{array}$} & Cercospora & 3,0 & 7,3 & 5,7 & 22,3 & 14,0 & 6,3 & 100,0 \\
\hline & Fusarium & 0,3 & 3,7 & 46,3 & 1,7 & 1,7 & 1,0 & 100,0 \\
\hline & Phomosis & 0,3 & 2,0 & 6,0 & 0,3 & 0,0 & 0,0 & 66,70 \\
\hline & Aspergillus & 2,7 & 1,0 & 0,0 & 6,0 & 5,7 & 4,3 & 83,33 \\
\hline & Penicillium & 0,3 & 0,0 & 0,7 & 0,0 & 0,3 & 0,3 & 66,70 \\
\hline & Colletotrichum & 0,0 & 0,0 & 0,0 & 0,0 & 0,0 & 0,0 & 0,00 \\
\hline
\end{tabular}

Table 8. Seed sanitary quality ( $\%$ of pathogen occurrence) for soybean seed lots from a seed company of the Canoinhas/ SC location, sampled along three stages of the production chain.

\begin{tabular}{|c|c|c|c|c|c|}
\hline \multirow{4}{*}{ TIME } & \multirow{4}{*}{ GENUS } & \multicolumn{3}{|c|}{ COMPANY } & \multirow{4}{*}{ INCIDENCE (\%) } \\
\hline & & & $\mathbf{H}$ & & \\
\hline & & \multicolumn{3}{|c|}{ CULTIVAR } & \\
\hline & & NK7059 & SYN 3358 & SYN1049 & \\
\hline \multirow{6}{*}{$\begin{array}{l}\text { RECEPTION AT } \\
\text { SPU }\end{array}$} & Cercospora & 10,3 & 10,7 & 14,7 & 100 \\
\hline & Fusarium & 21,7 & 21,7 & 14,7 & 100 \\
\hline & Phomopsis & 1,7 & 11,0 & 11,7 & 100 \\
\hline & Aspergillus & 0,0 & 0,0 & 0,0 & 0,00 \\
\hline & Penicillium & 0,0 & 0,0 & 0,0 & 0,00 \\
\hline & Colletotrichum & 0,0 & 2,0 & 0,0 & 33,3 \\
\hline
\end{tabular}


continuação

\begin{tabular}{cccccc}
\hline & Cercospora & 10,3 & 4,7 & 0,0 & 66,7 \\
& Fusarium & 1,0 & 14,0 & 3,0 & 100 \\
END OF & Phomopsis & 0,7 & 4,3 & 0,7 & 100 \\
PROCESSING & Aspergillus & 4,3 & 16,7 & 43,7 & 100 \\
& Penicillium & 0,0 & 0,0 & 0,0 & 0,00 \\
& Colletotrichum & 0,0 & 1,0 & 0,0 & 33,3 \\
\hline & Cercospora & 1,0 & 0,3 & 6,0 & 100 \\
BEFORE & Fusarium & 3,0 & 7,0 & 1,7 & 100 \\
MARKETING & Phomopsis & 0,7 & 1,7 & 0,3 & 100 \\
& Aspargillus & 1,7 & 25,0 & 10,7 & 0,00 \\
& Penicillium & 0,0 & 0,0 & 0,0 & 0,00 \\
\hline
\end{tabular}

Since many pathogens were found in the seeds analyzed, seed treatment should be established as a routine quality control practice among the soybean seed producers of the state of Santa Catarina, in order to warrant seed lots quality standards.

\section{Conclusions}

The seed processing at seed processing unit increases physical purity of seed lots.

The processes used by seed companies analyzed are not effective in removing seeds from other cultivars.

Lots of soybean seeds have mechanical damage at all evaluation times, from the reception at seed processing unit even before marketing, regardless of the beneficiation process, the company or the cultivar analyzed.

Soybean seeds produced in the state of Santa Catarina show pathogen contamination, so that seed treatment is recommended.

\section{References}

BALDUCCHI, A. J.; McGEE, D. C. Environmental factors influencing infection of soybean seeds by Phomopsis and Diaporthe species during seed maturation. Plant Disease, St. Paul, v. 71, n. 3, p. 209-12, 1987.
BINO, R. J.; JALINK, H.; OLUOCH, M. O. Pesquisa para o aprimoramento de tecnologia de sementes. Ciência Agrícola, Alagoas, v. 55, p. 19-26, 1998. Número Especial.

BRASIL. Ministério da Agricultura, Pecuária e Abastecimento. Regras para análise de sementes. Brasília: MAPA/ACS, 2009. 395 p.

CARVALHO, N. M.; NAKAGAWA, J. Sementes: ciência, tecnologia e produção. 4. ed. Jaboticabal: FUNEP, 2000. $588 \mathrm{p}$.

COMPANHIA NACIONAL DE ABASTECIMENTO - CONAB. Acompanhamento de safra brasileira: Décimo segundo levantamento grãos safra 2012/2013. Brasília: CONAB, set. 2013. Disponível em: $<$ http://www.conab.gov.br/OlalaCMS/uploads/ arquivos/13_10_16_14_32_01_boletim_portugues_-setembro_2013.pdf $>$. Acesso em: 24 fev. 2014.

COSTA, N. P.; FRANÇA NETO, J. B.; HENNING, A. A.; KRZYZANOWSKI, F. C. Zoneamento ecológico do Estado do Paraná para produção de sementes de cultivares precoces de soja. Revista Brasileira de Sementes, Brasília, v. 16, n. 1, p. 12-19, 1994.

COSTA, N. P.; MESQUITA, C. M.; MAURINA, A. C.; FRANÇA NETO, J. B.; PEREIRA, J. E.; KRZYZANWSKI, F. C.; HENNING, A. A. Avaliação da qualidade de sementes e grãos de soja provenientes da colheita mecanizada em diferentes regiões do Brasil. Engenharia Agrícola, Jaboticabal, v. 22, n. 2, p. 211-19, 2001.

COSTA, N. P.; OLIVEIRA, M. C. N.; HENNING, A. A.; KRZYZANOWSKI, F. C.; MESQUITA, C. M.; TAVARES, L. C. V. Efeito da colheita mecânica sobre a qualidade da semente da soja. Revista Brasileira de Sementes, Brasília, v. 18, n. 2, p. 232-237, 1996. 
FESSEL, S. A.; BARRETO, M. Avaliação da qualidade fisiológica e sanitária de sementes de amendoim durante o beneficiamento. Revista Brasileira de Sementes, Brasília, v. 22, n. 2, p. 126-130, 2000.

FRANÇA NETO, J. B.; HENNING, A. A. Qualidade fisiológica e sanitária de sementes de soja. Londrina: EMBRAPA-CNPSo, 1984. 39 p.

FRANÇA NETO, J. B.; KRZYZANOWSKI, F. C.; COSTA, N. P. Teste de tetrazólio em sementes de soja. Londrina: EMBRAPA-CNPSo, 1998. 72 p.

GOULART, A. C. P. Fungos em sementes de soja: detecção e importância. Dourados: EMBRAPA-CPAO, 1997. $58 \mathrm{p}$.

HAMER, E.; PESKE, S. T. Colheita de sementes de soja com alto grau de umidade I-qualidade física. Revista Brasileira de Sementes, Brasília, v. 19, n. 1, p. 106-110, 1997.

HENNING, A. A. Patologia de sementes. Londrina: EMBRAPA-CNPSo, 1994. 43 p.

KRZYZANOWSKI, F. C.; FRANÇA NETO, J. B. Reportagem de capa - set./out. 2003. Revista Seed News, Pelotas, ano VII, n. 5, p. 21-23, 2003.

LUCCA FILHO, O. A.; FARIAS, C. R. J. Patologia de sementes. In: PESKE, S. T.; VILLELA, F. A.; MENEGHELLO, G. E. Sementes: fundamentos científicos e tecnológicos. Pelotas: UFPel, 2012. p. 273369.

MACHAdO, A. A.; CONCEIÇÃO, A. R. Programa estatístico WinStat: sistema de análise estatístico para Windows. Pelotas: UFPel, 2003.

MENTEN, J. O. M. Prejuízos causados por patógenos associados às sementes. In: MENTEN, J. O. M. (Ed.). Patógenos em sementes: detecção, danos e controle químico. Piracicaba: FEALQ, 1991. p. 15-36.
MESQUITA, C. M.; COSTA, N. P.; PEREIRA, J. E.; MAURINA, A. C.; ANDRADE, J. G. M. Colheita mecânica da soja: avaliação das perdas e da qualidade física do grão. Engenharia Agrícola, Jaboticabal, v. 18, n. 3, p. 44-53, 1999.

PASCHAL, E. H.; ELLIS, M. A. Variation in seed quality characteristics of tropically grown soybeans. Crop Science, Madison, v. 18, n. 5, p. 837-40, 1978.

PESKE, S. T.; BAUDET, L. Beneficiamento de sementes. In: PESKE, S. T.; VILLELA, F. A.; MENEGHELLO, G. E. Sementes: fundamentos científicos e tecnológicos. Pelotas: UFPel, 2012. p. 423-480.

PESKE, S. T.; VILLELA, F. A. Secagem de sementes. In: PESKE, S. T.; VILLELA, F. A.; MENEGHELLO, G. E. Sementes: fundamentos científicos e tecnológicos. Pelotas: UFPel, 2012. p. 371-421.

POPINIGIS, F. Fisiologia da semente. Brasília: AGIPLAN, 1985. 289 p.

SINCLAIR, J. B. Latent infection of soybean plants and seeds by fungi. Plant Disease, St. Paul, v. 75, n. 3, p. 220-224, 1991.

SINCLAIR, J. B. Compendiun of soybean diseases. 2. ed. St. Paul: The American Phytopathological Society, 1982. $104 \mathrm{p}$.

TEKRONY, D. M.; EGLI, D. B.; STUCKEY, R. E.; BALLES, J. Relationship between weather and soybean seed infection by Phomopsis sp. Phytopathology, Madison, v. 73, n. 6, p. 914-8, 1983.

VICENZI, D. Indicadores de produção no beneficiamento de sementes de soja na C.Vale-Unidade de Faxinal dos Guedes/SC. Pelotas, 2005. Dissertação (Mestrado em Ciência e Tecnologia de Sementes) - Ciência e Tecnologia de Sementes. Faculdade de Agronomia Eliseu Maciel. Universidade Federal de Pelotas, Pelotas. 